\title{
Correspondence of Charles Darwin on James Torbitt's project to breed blight-resistant potatoes
}

\author{
M. DEARCE \\ Smurfit Institute of Genetics, Trinity College, Dublin 2, Ireland (email: mdearce@tcd.ie).
}

\begin{abstract}
The most prolific of Darwin's correspondents from Ireland was James Torbitt, an enterprising grocer and wine merchant of 58 North Street, Belfast. Between February 1876 and March 1882, 141 letters were exchanged on the feasibility and ways of supporting one of Torbitt's commercial projects, the large-scale production and distribution of true potato seeds (Solan um tuberosum) to produce plants resistant to the late blight fungus Phytophthora infestans, the cause of repeated potato crop failures and thus the Irish famines in the nineteenth century. Ninety-three of these letters were exchanged between Torbitt and Darwin, and 48 between Darwin and third parties, seeking or offering help and advice on the project. Torbitt's project required selecting the small proportion of plants in an infested field that survived the infection, and using those as parents to produce seeds. This was a direct application of Darwin's principle of selection. Darwin cautiously lobbied high-ranking civil servants in London to obtain government funding for the project, and also provided his own personal financial support to Torbitt.
\end{abstract}

KEY WORDS : Belfast - famine - Ireland - nineteenth century - Phytophthora - potato cultivars.

\section{INTRODUCTION}

The repeated potato-crop failures of the nineteenth century had most acute consequences in Ireland, but also throughout much of Europe (Bourke 1962, 1964, 1993). Often the cause was a devastating disease, the late blight, due to the pathogenic fungus Phytophthora infestans (Mont.) de Bary (syn. Peronospora infestans (Mont.) Casp.) originating in the Andes in South America (Gómez-Alpizar et al. 2007). Apart from the Great Famine of 1845-1849, there were in Ireland several minor famines (O'Brien 1896; Salaman 1949: 603; O'Neill 1995: 204) in 1860, 1861, 1862, 1879 (this triggering the Select parliamentary committee on the failure of the potato crop, which reported in 1880; Anonymous 1880), 1885 , and on three occasions in the 1890s.

Solanum tuberosum L. is capable of reproducing both sexually and asexually. In cultivation, potatoes are generally propagated asexually, simply by cutting the tubers into portions (the setts or sets), each bearing at least one bud ("eye"), and planting these in the ground (Salaman 1910, 1949). Confusingly, the tubers used by farmers and gardeners to produce the setts are termed "seed potatoes" although there are no true seeds involved.

Sexual reproduction, involving self-pollination or, more rarely, cross-pollination, results in fruits containing seeds ("true potato seed"). However, growing crops of potatoes starting with "true potato seeds" is much more time-consuming and costly than using setts, and has never been an option for subsistence farmers, as most in Ireland were (O'Brien 1896: 29). Alexander Napier, one of Torbitt's collaborators (Torbitt 1876: 48) mentioned how, when showing Torbitt's seeds to his farming friends and telling them that he intended to grow potatoes from them, "they laughed at the idea of any sized tubers growing from such a small seed". 
Sexual reproduction results in variation, each individual seedling being slightly different from others. If a seedling has beneficial traits, it may be selected for further asexual propagation and the progeny would then constitute a new "variety" (Salaman 1949: 159). (A "variety" that is maintained in cultivation is called a cultivar, and although this is a modern term it will be employed throughout this paper, except in direct quotations, because it is more precise than "variety".) Potato cultivars are usually selected for particular traits of the tuber including, for instance, shape, colour and texture of the skin or of the "flesh", yield, or optimal time for harvesting (early or late) (Salaman 1910). Another trait is disease-resistance, including resistance to late blight. In the second half of the nineteenth century, new cultivars were not the results of purposeful hybridization (Salaman 1949: 167); they were usually fortuitous selections either of chance seedlings or of chance somatic mutations that sometimes occur in crops which are asexually propagated (Davidson 1928a, 1939).

A feature of potatoes that puzzled nineteenth-century growers, including Torbitt (1875, 1876), was that after a number of years (one to a few decades were often cited) of vegetative propagation (by setts), a cultivar "degenerated" or became "worn out". Degeneration, often associated with stunted growth and curled foliage, led to diminishing yields even when the potatoes were grown in favourable conditions. All potato cultivars tended to "degenerate", but it was observed that this could be delayed by planting tubers of the same cultivar obtained from other farms. These observations had been made by Hunter already in 1773 (quoted by Davidson 1928a: 380) and were well known at the time of the Select Committee in 1880 . After the 1845 attack of late blight, it was noticed that cultivars gradually became less resistant to it, and many actually disappeared (Anonymous 1880). Hence the search for blight-resistant cultivars.

\section{POTATO TRADE}

In 1879 in Ireland, according to returns from the Board of Trade, 842,621 acres were devoted to potato cultivation; the comparable figures for England were 323,992 acres, Wales 42,609 acres, and Scotland 174,743 acres (Clark 1880). In an average year, at that period, the Irish crop reached around three million tons and fetched $£ 12$ million. After 1845, cultivar development was essential in commercial potato production. Its importance can be seen, for instance, from The Times' report on the 1879 Potato Show at the Crystal Palace (Anonymous 1879). At this yearly event, 70 exhibitors showed 2,000 entries, competing for awards offered by different firms and private persons. Such attendance, lower than in previous years, took place in spite of the fact that 1879 had been a particularly bad year for blight in the United Kingdom.

Salaman (1949: 159-187), following Davidson (1939), traced the history of many cultivars popular in Britain and Ireland, from before the famine up to the 1930s. It was mainly the failure of the cultivars 'Cups' and 'Lumper' that caused the Irish famine, but all other pre-famine cultivars were also susceptible to blight.

As stated at the Select Committee (Anonymous 1880), potato cultivar production is clearly different from production for household consumption, and it is a long-term investment requiring considerable resources of land and labour. William Paterson (1810-1870), a famous potato-grower from Dundee is said to have lost $£ 7,000$ in connection with raising of new cultivars, while still in 1902 tubers from newly launched cultivars having 
the right characteristics could fetch enormous prices for a few days, some growers paying up to $£ 100$ for one of these tubers (Davidson 1939: 16).

\section{DARWIN CORRESPONDENCE STUDIES}

A preliminary edition of Darwin's correspondence was produced by his son, Francis, in 1887. Burkhardt and Smith's Calendar of the correspondence of Charles Darwin, 1821-1882 (1994) organizes and gives brief summaries of nearly 14,000 letters written or received by the naturalist. Quantitative analyses of this Calendar by Veak (2003) indicated the existence of a number of relatively minor correspondents who nonetheless occupied considerable attention from Darwin. These studies are now facilitated by the online Darwin Correspondence Project ${ }^{1}$ at Cambridge University Library.

The transcripts that follow were obtained as raw digital copies from the database maintained by the Project, and were edited by the present author to remove unreadable wordprocessing codes and some formal phrases at the beginning or end of most of the letters. Both the Calendar (Burkhardt and Smith 1994) and Veak's study (2003), and searches on the online (public) database of the correspondence indicate that 93 letters were exchanged by Darwin and James Torbitt between 1876 and 1882. ${ }^{2}$ However, to get a fuller picture of the extent of Darwin's involvement in Torbitt's project, it is necessary to consider a further 48 letters in which Torbitt's project was, at least in part, the subject. These were exchanged between Darwin and Sir Joseph Hooker (five letters) ${ }^{3}$, James Caird of the Board of Trade (7 letters) ${ }^{4}$, and Thomas H. Farrer, also of the Board of Trade and brother-in-law of the Chancellor of the Exchequer (32 letters) ${ }^{5}$, or these among themselves, or with others (four letters). ${ }^{6}$ Of these 141 letters, 13 were written in 1876, and only three in 1877 . More than 50 letters per year were exchanged in 1878 and 1880, of which 26 and 29, respectively, were written in the months of March.

Although the contents of these letters is known, at least through the short abstracts in Burkhardt and Smith's Calendar (1994), the issue that ties them together was not fully identified until the study of Evans et al. (1996). Having studied the contents of all 141 letters, a little-known aspect of Darwin's activity during the last years of his life emerges, namely, the use of his reputation and his social contacts, as an established man of science and member of the establishment, to obtain government backing for Torbitt's attempts to breed blight-resistant potatoes from true seed.

\section{JAMES TORBITT OF BELFAST}

James Torbitt (c. 1822-1895) was a Belfast-based spirit merchant with premises at 58 North Street during the period discussed here (Evans et al. 1996; Clarke 1986).

When describing Charles Darwin's correspondence with David Moore (of the Royal Botanic Gardens, Glasnevin, Dublin), Nelson and Seaward (1981) mentioned James Torbitt, based on Francis Darwin's (1887) edition of his father's correspondence. Torbitt himself quoted from Francis Darwin's work in one of his advertisements (see below), as it contained nominal references to him. Nelson and Seaward (1981) and Nelson (1983, 1995: 16) speculate that Moore may have co-operated with Torbitt, but neither man mentioned the other in their known publications, and there is no trace in Burkhardt and Smith (1994) that 
Darwin, who corresponded with both on the subject of potatoes (Nelson 1981), facilitated their contact. Veak (2003) registered Torbitt as a minor correspondent but neither potatoes nor potato blight were mentioned.

Initially, Torbitt (1875: 118; see also Anonymous 1874) was not concerned with the external cause of late blight. Rather, he proposed a "law of vegetative multiplication" (Torbitt 1875: 118; 1876: 32) to explain decay in potato cultivars. He proposed that each individual plant has by nature a given span of life according to its species. This hypothesized 'internal clock' that in every species measures the life span of the individual from fertilization to its natural death was set to start a new cycle in the offspring resulting from sexual reproduction, but continues counting for the results of vegetative multiplication which are simply parts of the original individual and not new individuals. He saw in the old age of the plants continually propagated by the set method the cause of their increased vulnerability to Phytophthora. He presented these ideas in a lecture titled on "The cause of the potato disease and the means of its prevention" delivered to the British Association for the Advancement of Science (BAAS) in Belfast on Thursday 20 August 1874 (Anonymous 1874). At the meeting, William Carruthers, Keeper of Botany at the British Museum, London, dismissed Torbitt's theory, arguing that the disease would affect the potato plant regardless of the method used for the tuber's reproduction. Torbitt repeated his ideas again in 1875, at a different forum in Belfast (Torbitt 1875), with a similarly disappointing result.

Torbitt's conviction that he had the solution to the potato degeneration problem, and indirectly to blight attacks, was such that in 1876 he decided to canvas all members of both houses of the United Kingdom parliament, as well as the principal landowners of Ulster, by printing and distributing his ideas in a 60-page pamphlet: A treatise on the cultivation of the potato from the seed, having for proposed results the extinction of the disease (Torbitt 1876). Each copy which he distributed was accompanied by a packet of 9,000 potato seeds. In this pamphlet, which has the Latin epigraph "Cras credemus" on the cover and title-page, Torbitt (1876) reported the experiences of 22 farmers throughout the United Kingdom who had participated in a large field-experiment conducted with his seeds, planted in the spring of 1875. Five farmers reported totally disease-free crops. Of the 17 with diseased crops, eight reported better than $80 \%$ disease-free; five reported, respectively, better than $70 \%$, twothirds, less than $50 \%, 40 \%$, and $10 \%$ disease free; two reported disease in the leaves but not in the tubers, and two reported accidental loss of crop. In all cases, the healthy plants had grown within short distances of diseased plants.

To referee in his dispute with Carruthers on methods to improve the potato, Torbitt sought Darwin's expertise. Once Darwin had reassured Torbitt his methods were sound, he sought permission to use Darwin's name in his press campaign. Initially Torbitt did not seek Darwin's financial assistance nor Darwin's influence in the British establishment to further his cause with the government. Darwin volunteered both.

\section{RECORD OF TORBITT'S POTATO PROJECT IN DARWIN'S CORRESPONDENCE}

Torbitt's first letter to Darwin, dated 24 January 1876, enclosed a copy of an article about the potato he had published in a "Belfast Journal". 7 Torbitt asked Darwin: "What is an individual?" As noted, in Torbitt's opinion, all potatoes grown from a set were parts of the same individual and thus they were as old as the parent plant. Having received 
Darwin's encouraging response (dated 26 January 1876) ${ }^{8}$, Torbitt apparently placed advertisements in various newspapers, making use of Darwin's name as guarantee of the sound scientific base of the true potato seed project, although none of these advertisements has been traced.

Torbitt also placed three identical advertisements in The Times of London on Saturday 21 February 1876, and the following Monday and Tuesday, as follows:

EXTINCTION OF POTATO DISEASE, with doubled or trebled crops - Modus operandi - Grow from the seed. Exposure of plants to full force of infection. Destruction of those which succumb. Propagation of the rest by the sett. (In all places some plants will repel the attack of the parasite: in some, all). Seed supplied gratis. Address Robertson, Brooman and Co.; 150 Fleet Street, London. Or James Torbitt, Belfast, Ireland.

These advertisements met with little response (Torbitt 1876). On 1 April 1876 Torbitt $^{9}$ sent $^{-1}$ Darwin the first copy of his pamphlet, and some tubers predicting that these should grow disease-free. He added:

The other small tubers are each different and new varieties, grown from the seed last year. They have no merit further than this, that every tuber of each of these plants absolutely resisted the disease last season; they at the same time growing in a perfect hot-bed of disease. It now remains to be seen will they continue to resist?

I am myself perfectly satisfied, I have no fear at all on the subject; perhaps I am too sanguine, but I am fully persuaded that your last letter is in reality the death-knell of the peronospora, and with your permission (if you can permit it) I shall make Kolokol ${ }^{10}$ ring it out from the Kremlin through the furthest depths of Siberia before the Autumn is over. And as the first step may I beg of you to read enclosed advertisement, and if you approve of it have the goodness to let it go forward; and if the accompanying twenty pounds does not buy enough publicity in the Times for my purpose I shall try a hundred.

In reply, on 4 April 1876, Darwin ${ }^{11}$ again stated that in his opinion Torbitt was working on sound principles but denied permission to publish his previous letter as part of an advertisement. Torbitt replied three days later, again seeking permission to publish, a request repeated on 21 April 1876. Eventually, perhaps by mistake, Torbitt did send the advertisement mentioning Darwin to the papers.

Darwin $^{12}$ reprimanded Torbitt for his unorthodox methods, although eventually he did agree that Torbitt could use paragraphs from their private correspondence in private conversations with agriculturists, not just because he was aware of the ravages of the famine but because he was convinced of the soundness of the science. Darwin wrote:

I very much dislike my letters being published as advertisements, but I would perhaps submit to this, though extremely disagreeable to me, if I could believe that it would do any good. I hope that you will permit me to speak frankly. It seems to me quite useless to advertise any intended plans, until crowned with success. I am convinced that any one reading your advertisement would consider you a fanatic; and supposing that you succeeded in obtaining a good variety of the plant, which resisted the disease, it would be incomparably more difficult to persuade the public of your success if people thought you a fanatic and consequently would not trust your statements. Whatever weight my name may have you could use to persuade persons privately, to raise seedlings, and this would be amply sufficient. Under these circumstances I return you the MS and draft; for I am unwilling to aid in what I believe will be a step injurious to your success.

In his response, Torbitt disclosed the full extent of his trespasses. He explained that he had applied to John Murray, Darwin's publisher, to reproduce a page from one of Darwin's works in A treatise on the cultivation of the potato ..., and that he thought that having this, publishing the private letter would make little difference to Darwin. Torbitt wrote ${ }^{13}$ :

Perhaps I am an enthusiast to fanaticism, on a given subject, perhaps I only look at facts with a fearless eye. I believe nothing excepting only that there is something. But I suspect that you have made a distinct step in advance, as regards mans knowledge of that which is. As regards the advertisement, my mind misgave me, and I telegraphed Robertson tho not to order it, even if you sent it, lest you might not wish for it. 
One of the last things I would wish to do would be anything disagreeable to you, but unfortunately I sent the paper and your letter of 4th. April not only to the members of the Legislature but to the Editors of the papers and to the Landlords of Ulster. But I really think and anxiously hope you will not regret it. It has done good. (without it what impression could I have expected to make?) I am being thanked on all hands for what I have done, as see for instance, the enclosed note from the Duke of Bedford.

I thought I had liberty to publish, and did not discriminate, and your name shall never again be used by me except "privately to persuade persons to raise seedlings".

I am perfectly well aware that your writing to me at all is an honor, and that your writing to me frankly is a high honor.

The incident would be forgotten and confidence fully restored, but Darwin's reasoning for not publishing ideas before they were fully matured and tested proved to be right.

Subsequently Torbitt was able to add to the opinions collected in his pamphlet. Lord Stanley of Alderly Park (Chamberlain 2004) had written that "I find that potatoes raised this year from seedlings grown from your seed sown last year, are of a good size and have kept sound up to this date, whilst the ordinary potatoes about here had begun early to become unsound." ${ }^{14}$ Other testimonials came from Victor Kennedy ${ }^{15}$, George Callwell ${ }^{16}$, William Meredith $^{17}$ and other Irish farmers who had grown his potatoes.

The season 1877-1878 appears to have gone well for Torbitt, as he was able to state that "the sales of varieties had been enough" 18 to partly finance the experiments.

\section{DARWIN OFFERS HIS ASSISTANCE}

The first indication of Darwin's active involvement in the true potato seed scheme, other than by lending his name to the cause, came on 26 February $1878^{19}$ more than two years after Torbitt's first letter, and after the first relatively successful potato campaign. The proposal was apparently unsolicited.

I know little of public affairs, but fear that our governing men are so ignorant of science and so immersed in political squabbles that they will do nothing. It would be a great misfortune if your seeds are wasted. I would suggest your sending a copy of your letter to T. H. Farrer, Esqre., Board of Trade, Whitehall, London. He is the head of office, and a friend of mine and scientific. I am going to London to-morrow for change and rest, as I am very poorly (and this must excuse this ill-expressed and ill-written note) and will see Mr. Farrer and talk to him on the subject. Mr. Farrer is brother-in-law of Chancellor of the Exchequer. I fear that there will be great difficulties. Could you undertake the continuation of the experiments, if aided by a moderate grant of money or a subscription from a few friends of the cause? They are so overworked at the R. Gardens at Kew I do not think the work could there be undertaken.

Send a copy to Sir J. Hooker, K.C.S.I., Kew Gardens: mark with red or blue passages quoted from me, as this will call his attention to them. If even a moderate stock of a sound variety was once raised I should think a great salesman like the Messrs. Carter would cultivate and dispose of them; and thus they would be best distributed. You will understand that I know nothing of your circumstances and one of Mr. Farrer's first questions probably will be "Does Mr. Torbitt require to be repaid for expences already incurred? or, has he worked solely for patriotic purposes?" Will you kindly answer immediately my several questions ....

This was followed on 28 February 1878 by two letters. Darwin wrote as follows to Torbitt ${ }^{20}$;

Too unwell to call on Mr. Farrer so I asked him to call on me - have had long interviews - will consider your printed letter and if he agrees with me (as I think and hope he will,) will consider what Department of Government to apply to - thinks Duke of Richmond - says Government will probably apply to Sir J. Hooker for advice, so I have written to him, urging him to read carefully your printed letter when he receives a copy. I have added some fresh arguments. Can write no more.

Forwarded the substance of your Telegram to Mr. Farrer. Seems to me important to know this - Can you specify what sum of money you would require, making it as moderate as you can? Mr. Farrer says the Eastern question is much against any attention being paid to any new subject. 
The second letter was to Hooker ${ }^{21}$, who could find other uses for Torbitt's idea;

You will probably receive a printed letter from Mr Torbitt, giving the results of the selection \& crossfertilisation of Potatoes. I beg you to read it with care; for I have just had interview with Farrer on subject \& he is going to speak to the Duke of Richmond's Secretary, \& other influential men, if after considering the subject, he should agree with me that it would be a dreadful pity if hundreds of thousands of cross-fertilised seeds from already partially selected parents were thrown away.

He thinks that if the Government is inclined to take it up, they will apply to you for advice. - Mr Torbitt says he cannot afford to go on without some aid in money. - If aided he will continue his experiments.

Pray reflect on difference in varieties of Pots in resisting Phylloxera - of apples in resisting Coccus - of Peaches in resisting mildew \&c \&c. - These cases make me hopeful that Mr. T. may succeed, \& indeed he seems to have been partially successful already, but he is dreadfully enthusiastic. - He does not want payment for 3 past years only aid in future. - I can write no more. - Am so unwell that we have come to London for change \& rest.

On 1 March 1878, Darwin wrote again to Torbitt ${ }^{22}$ explaining his actions so far and making another generous and as far as we know unsolicited offer.

I have just received your letter which explains everything most clearly. I heard from Mr. Farrer last night: on reflection, he determined to call on Mr. Caird, who is a great authority on agriculture, as you no doubt know, and he writes to me that "Caird takes it up warmly and he will see the Agricultural Society people".

The Society has land and he believes that it will cultivate your seeds; and I have said that I feel sure that you will supply the Society with seeds and some tubers. I shall hear what is determined and will report to you; but this will probably take a little time. The Society will be an admirable means of distributing any fungousproof variety. I wrote last night to Mr. Farrer that it appeared to me highly advisable that you yourself should continue your experiments for some time, and that Government money would be well spent in aiding you; but whether he will apply to the Duke of Richmond I am doubtful.

Any how as so small a sum as $£ 100$ would enable and encourage you to go on, I pledge myself to transmit at any time a cheque of this amount to you, unless you obtain Government aid. So that I trust you will, as soon as the proper season comes, sow a good many of your cross-fertilized.

Keep this note, in case of my death, on account of my pledge.

By 12 March 1878, Darwin confided to Hooker that he had lost hope of raising money from the government. ${ }^{23}$ They would set up a private subscription instead ${ }^{24}$, and so between March 1878 and May 1881, through Darwin's initiative, Torbitt received $£ 410^{25}$ from Darwin’s friends and relatives. A letter, dated 2 March 1878, from James Caird of the Board of Trade to Thomas H. Farrer ${ }^{26}$ contained a reference to William Carruthers, who had opposed Torbitt's scheme at the Belfast meeting of the BAAS in 1874. Carruthers's views had not changed, as Caird found;

\section{Dear Mr Farrer.}

In case I may miss you at the Board of Trade I write a note to tell you what I have done. In the first place I saw Mr Jenkins the Secretary of the Royal Agric. Soc; who says he has no doubt that the Experimental Committee would undertake a trial of the Potato plants in various localities on being secured in the matter of expense.

Then I went to Mr Carruthers, F.R.S. the Botanist of the Society \& of the British Museum, and had a long conversation with him, the gist of which you will find in the accompanying letter which I requested him to write to me.

He does not think Mr Torbitt has got so far advanced in his experiments, as were the hard potatoes submitted to trial by the Royal Agr. Society in 1874. I send an account of these experiments, and I think you might send it \& Mr Carruther's letter to Mr Darwin for his consideration.

Then I would suggest a meeting of Mr Darwin, Mr Carruthers, yourself \& me to talk the matter over, before asking the Government to undertake any expense. 
On 4 March 1878, Darwin wrote to Farrer $^{27}$ dismissing Carruthers' opinions as unfounded;

As you have been so very kind, I should like to report Progress on Potato Question - Mr. Caird called yesterday, and I was very glad to see him, nobody could be more energetic \& obliging. I quite forgot to return to him the enclosed documents, \& this is one reason why I now write to you - The Agricult. Soc. will not do, as Mr. Caird will explain - I am sure there is very little weight in Mr. Carruther's objections.

Mr. Torbitt telegraphs. (!) that now he has got my $£ 100$, seeds shall be sown tomorrow. He says that to continue work with the tubers also. he ought to have another $£ 100-$ He adds that he hopes he may be able to go on next year without money aid - I have written advising him to moderate the extent of his trials. Mr Caird took away the long letter which I had written to you when we thought of the Agricult Soc - He asked whether he might show it to anyone \& I agreed but I could have improved it greatly. so far as relates to shewing anyone that it is the most hopeful scheme. - I daresay if I had strength to get up a memorial with a few good signatures we might have got a small grant from Government; but I have not the strength.

Hooker writes strongly that he believes the plan to be the right one; \& has given analogous advice to coffee growers in India - Mr Caird did not seem to think it hopeless to get aid somehow; but I doubt greatly

I shall ever feel obliged for your kindness and wisdom of your advice.

Torbitt's project illustrated in practice the idea of selection (Torbitt 1876: 57), which was a controversial issue among naturalists from the time of the publication of On the origin of species in 1859, and of the advantages of cross-breeding (Darwin 1859), hence Darwin's added interest. He was again ready to help, as the following letter ${ }^{28}$ to Farrer, dated 23 October 1879 illustrates.

I should like you to read the 2 letters in Newspapers sent, which will not take more than 5 minutes \& they need not be returned. I do so because you were so kind as formerly to aid me on the subject - The letters are written by men who do not understand Mr Torbitts main Principle of Selection but they show fairly favourable results considering what a dreadful season this has been for the Potato.

I heard from Mr. Torbitt about 2 months ago in much distress as his wife had just been operated on for cancer. He says trade was so bad he feared he should be ruined, but he would go on as long as he could with his experiments - Unless he is aided I fear all his work will be thrown away but he asks for nothing - What a pity there cannot be 2 sets of men in our Government, - one to do all the miserable squabbling \& the other to attend to the real interests of the country.

A similar letter, dated 1 November 1879 , went to Torbitt $^{29}$ who replied ${ }^{30}$ with his first request for financial help, £500. Torbitt included some observations on the 'Champion' potato, a cultivar produced by John Nicoll in 1863 (Anonymous 1880):

I duly received your much esteemed letter of 27th Decr. last and now write to suggest might it be possible to borrow $£ 500$ from the Government for the purpose of carrying on the work; giving the new varieties of the potato as security for repayment of the loan and of your advance - A single variety of the plant "The Champion" which is now spreading all over the kindgom has been worth many thousands of pounds to the country within the last few years, and doubtless it will be worth a great many more before it disappears so that the security ought to be good - The "Champion" was grown from a seed sown in the Spring of 1863 and latterly it has become more and more susceptible to the Disease and less and less able to produce its fruit Watching it for the last two seasons I found all the Stamens abnormally twisted and all the flowers dropped off. - Last year as I am informed it did not produce any fruit anywhere and unquestionably new varieties should be coming forward to replace it - In the present state of affairs with the whole kingdom "hungry" for potatoes such as we had fifty years ago, it will be too bad if $£ 500$ stops the way. And yet I cannot devote another shilling to the work, although I thought I could afford to spend a thousand a year on it when I commenced -

Caird communicated with Darwin later ${ }^{31}$, on 25 March 1880.

Re. Mr. Torbitt's experiments. I hope soon to be able to explain to the several gentlemen interested all that you have so kindly communicated. The scale on which the experiment is carried on is much larger than I imagined - and one can more easily understand the need of pecuniary help. As to the $£ 60$. sent by me. (which 
you may count as $£ 50$. from the Messrs Morrison $\& £ 10$. from me - Sir Julian Goldsmith not having paid his we shall keep him in reserve for a future application if need be:) pray retain, till you think proper to make use of it for the object in view. You need not send any other receipt than the mention you make of it in your letter.

If Mr. Torbitt suceeds in getting a plant more than commonly capable of resisting the fungus we shall be all well repaid - \& my friends \& myself are perfectly satisfied to follow your lead in the matter. Mr Mulholland, M.P., a friend of mine, who lives near Belfast, has kindly undertaken as soon as his election is over, to visit Mr. Torbitt's experimental fields, and report the result. This I shall communicate to you.

I notice that Mr. Torbitt promises that his vigorous potatoes will enable the British farmers to compete sucessfully with America in all agricultural live stock! If he can give us a potato that will supply a sound vegetable for our people we shall be quite content.

The harvest of 1880 was one of the best on record, owing, perhaps, to the liberal supply of good seed potatoes provided in the spring by the Seed Supply Act, which released close to $£ 600,000$ for the purpose (O'Brien 1896: 285), although we do not know if any of this went to Torbitt.

With at least Darwin's partial and reluctant agreement, Torbitt felt that he had gained the freedom to refer to Darwin directly, in writing, when canvassing influential politicians privately to organize public funding for his venture. He wrote, among others, to the Chancellor of the Exchequer (as instructed by Darwin) in February $1878^{32}$, had a paper published in The Field on February $1879^{33}$, another full report in November $1880^{34}$, and an open letter to Gladstone in December $1880^{35}$, and in all of them mentioning Darwin as scientific guarantor. On 6 March 1880 Darwin himself considered writing a letter to The Times $^{36}$, but no such letter has been traced.

\section{SELECT PARLIAMENTARY COMMITTEE ON THE FAILURE OF THE POTATO CROP}

Parliament had discussed the problems caused by the failure of the Irish potato crops before, but in view of the disastrous crop of 1879, on 21 May 1880 a committee was formed again to inquire into the best means of diminishing the extent of these failures. It was becoming abundantly clear that the creation of new cultivars was both essential and beyond the means of any private individual.

The Select Committee was formed by 16 members. Among the scientific witnesses were Professor William Thiselton-Dyer FLS, Assistant Director of the Royal Botanic Gardens, Kew; William Carruthers, Keeper of the Botanical Department of the British Museum who had criticised Torbitt at the BAAS meeting in 1874; Professor Thomas Baldwin, Superintendent of the Agriculture Department of the National Board, Ireland, who had an interest in the study of animal and plant disease epidemics by statistical methods and who first proposed the view that the disease came from Peru; Dr J. A. Voeckler FRS, Consulting Chemist at the Royal Agricultural Society of England, and George Worthington Smith FLS, botanical illustrator and mycologist, credited in 1875 with the discovery of the cause of the potato blight. There was also a group of seven large-scale potato growers, including two from Ireland, Mr Robinson from County Dublin and Mr Coleman from Londonderry. In addition, the committee heard evidence from, among others, John Nicoll who had developed 'Champion', William Ingram, gardener to the Duke of Rutland, Mr Shuter, a potato salesman, and a Mr Thompsom who had a specific remedy the nature of which he did not disclose. 
The committee's work was thorough, reporting on 9 July 1880.

All witnesses concurred in the necessity for the production of new varieties, the growers among them saying that many varieties had disappeared, having become utterly "worn out", and that all had deteriorated in their disease-resisting powers. All agreed in the disease-resisting powers of the Champion variety, although this was bound to decay within a few years. The disease-resisting powers of a variety were thought to degenerate after about 20 years of its establishment. The witnesses agreed that the production of new varieties, from seed or possibly from the improvement of existing by careful selection of tubers is of considerable national importance, and that it does not offer to the individual who devotes himself to their production much hope for remuneration. Since the Royal Societies have not done much in this regard up to the present, it is the time for the Government to step in. In Ireland, the best plan would be to further extend the farms of the Agricultural Departments of the National Board, and to specifically direct the attention of the superintendent of the farms to researches on the potato disease, and to the creation, selection and establishment of new varieties of the potato.

Many of these recommendations were as Torbitt was suggesting, but the business was drifting away from him. Scottish growers clearly favoured the local 'Champion' cultivar, although on their own reckoning this should be degenerating soon. Torbitt had seen signs of its "decay" already in $1880 .{ }^{29}$

\section{TORBITT'S POTATO PROJECT AFTER 1882}

Eight years after Darwin's death, Torbitt was still trying to encourage the use of the true potato seed to produce blight-resistant cultivars. He felt then free to use his former mentor's name in advertisements in The Times and elsewhere. The idea of breeding potato cultivars for resistance to Phytophthora was spreading, propelled, at least in part, by Torbitt's enthusiasm.

No direct statement of Torbitt's intentions to give up his true potato seed project has been traced, and neither has proof of him getting substantial government commissions. Between 1880 and his death in 1895 his wine and spirits business thrived (Evans et al. 1996). Francis Darwin (1887: 3: 351), who reported talking to Torbitt in 1887, mentioned that he was still "raising varieties possessing well marked powers of resisting the disease". Torbitt also continued to publish advertisements in The Times. An advertisement published on 11 February 1888 (repeated four days later) read:

To the LANDOWNERS of the KINGDOM.- Proposed reinstatement of the value of land, by means of the cultivation of disease-proof, double tuber-yielding, immense quantities of edible fruit-bearing, and enormous quantities of excellent wine, brandy and jam producing POTATO CROPS.

Landowners are earnestly entreated to communicate with me, when full explanations and specimens of the products of the plant will be submitted.

Note. Darwin has left on record his opinion that to neglect to carry out this work would be a "national misfortune". See his Life and Letters, vol 3, page 349. And I am now prepared to supply the means of flooding the kingdom with millions of new varieties of the plant, possessed of the above-described capacities. These statements will at first be found to be incredible-incredible solely because they are new-but the facts exist, and the potato is, by at least twice, the most valuable plant which the earth produces. JAMES TORBITT, Belfast.

The advertisement published on 20 May 1890 was more succinct: “TO CAPITALISTS.Means of obtaining the vastest profits ever yet realized. Matter approved of by one of the highest authorities of the world. Please communicate with James Torbitt, Belfast, Ireland."

Already in March $1881^{37}$ Torbitt had written to Darwin saying that he is "pretty well disgusted by the apathy and stupidity he has found whilst trying to arise interest and support 
for his work". His advertisements in The Times fail to mention any such support as a way to create confidence in the potential customer, and they show him still seeking private funds ten years after the Select Committee had reported, in July 1880. His name is absent from the report of the contemporary Potato Show of 1879 (Anonymous 1879), as one of the better known growers or seed providers. In the death certificate his occupation is entered as "spirit merchant" (Clarke 1986: 150), indicating that this was his major activity towards the end of his life, although this is not an enterprise entirely unrelated to the potato (see his 1888 advertisement above). But most importantly, the 'Champion', a late-maturing cultivar, was credited with having saved its crop in 1879, when all other cultivars failed. From that time until 1894, the 'Champion' occupied $80 \%$ to $90 \%$ of the land under late potatoes in Ireland (Davidson 1939, O'Brien 1896). No other cultivar was ever so popular in Torbitt's own country.

It is arguable that Scottish growers were more subtle and successful at marketing. Another advertisement in The Times of 24 March 1880:

NOTICE.-The SCOTCH CHAMPION POTATO (Carter's select stock) as supplied to her Grace the Duchess of Marlborough's Relief Fund and awarded a first-class certificate by the Royal Horticultural Society, with the following remarks.: "The Committee were of opinion that the Scotch Champion Potato was remarkable for resisting the disease, and is a potato of good quality." Price per sack, 28c : per bushel, 10s. 6d. : much cheaper per half-ton and ton. 20s. value carriage free.-CARTERS, The Queens Seedsmen, 237 and 238, High Holborn, London W.C.

This advertisement markets a potato identifiable by name, while Torbitt's seeds were countless and nameless, or at least he never identified them with a brand name. In fact, at least at the beginning, Torbitt was trying to spread a process, an idea, rather than a product, and for no profit. By proposing to grow potatoes from their true seed, he was trying to change age-old farming practices, and many of the smaller farmers received this with scorn (Torbitt 1875). Neither could he guarantee disease-free harvests, as his crops from true seed were inherently variable. His competitors also had their own mentors who gave support to independent reports of third parties who were in the potato business and were satisfied with the product. While Torbitt could mention an academic authority, Charles Darwin was, by his own admission, removed from the worlds of business and potato growing. The Scottish growers mentioned the price of their potatoes and named reputable suppliers. The cost and source of Torbitt's seeds had to be worked out privately.

\section{DISCUSSION}

Torbitt's work won Darwin's admiration: "If anyone ever deserved success, you do so, and I keep to my original opinion that you have a very good chance of raising a fungus-proof variety of the potato" (Darwin 1887: 3: 350). But the thrust of their correspondence as it developed, that is, obtaining substantial Government help, appears to have failed, otherwise there would have been no need for a private subscription. On 18 May 1881, Darwin pointed to a failure in communication skills when he admitted that he was sorry that Torbitt could not get his true potato seeds "well enough known to ensure a large sale". 38

Torbitt was partly right to link the phenomenon of degeneration of cultivars and vulnerability to blight with vegetative propagation as opposed to sexual reproduction. The topic had been discussed by scientists and growers for many decades (Davidson 1928a). We know now that Phytophthora overwinters in the tubers, so a round of sexual reproduction 
would produce initially uninfected plants. Growers had observed that late maturing cultivars, like the Champion, which reached the peak of their vigour (flowering) only after the blight appears, fared better than early maturers, that are already past their prime when the disease attacks. Very late seedlings are remarkably blight-free on their first year, though they may succumb in their second year, when they are planted from tubers and mature much earlier. We now know that late maturing cultivars that lose their initial resistance, have accumulated a large load of viral disease which results in their maturing one or two weeks earlier, being thus weaker at the optimum time of the blight (Salaman 1949: 175-176). Davidson (1928) was able to rejuvenate the Champion potato simply by ensuring that the stock chosen to start the process was absolutely virus free, and that no contamination took place while growing and expanding in the fields. Late maturation, yields, and disease resistance of the rejuvenated plants were as good as when the cultivar was introduced in the first place, 50 years earlier. This shows that it is possible to continue indefinitely the cultivation of any particular variety where favourable conditions exist (Davidson 1928b).

The beneficial effects of sexual reproduction among Torbitt's cultivars can now be explained as the result of new interactions of multiple alleles that are characteristic of quantitative and durable resistance to blight, like cuticle thickness and waxiness, optimal time to maturity, or robustness (Collins et al. 1999). This resistance is unspecific, not just to blight, a genetic quantitative trait. But Torbitt was distracted by the apparent high levels of resistance in the F1. Had he, or Darwin, suggested taking the resulting progeny, vegetatively propagating it and selecting for resistant cultivars over a number of clonal generations, he would have been arguably the father of potato breeding.

Growers and scientists looked for specific blight resistance not just among native Andean Solanum tuberosum taxa but also in other species of Solanum. Salaman narrated the finding of potatoes that were resistant to blight such as S. etuberosum (Salaman, 1910: 39), S. edinensis and S. demissum (Salaman, 1949: 176). However, it was also found that strains of Phytophthora infestans rapidly appeared that were able to overcome this resistance. Classic breeding experiments on $S$. demissum carried out in the 1950s and 1960s identified eleven of these dominant resistance genes (named R1 to R11). Blight-resistance is still an active research subject using molecular genetics methods (Milbourne et al. 2007: 216) and so is the use of hybrid true potato seed (Fuglie et al. 2001).

\section{ACKNOWLEDGEMENTS}

I am grateful to the directors of the Correspondence of Charles Darwin Project at the University Library in Cambridge for providing access to the private digital database containing the unpublished letters transcribed in this paper. I am also grateful to the Syndics of Cambridge University Library for permission to see unpublished documents and letters from the Darwin collection. This material as shown here is at a pre-publication stage and neither the Project nor Cambridge University Library can be held responsible for any errors of transcription remaining. My thanks also to Dan Milbourne, Research Officer at the Plant Biotechnology Programme, Teagasc, Crops Research Centre, Carlow, Ireland, for discussions and for letting me see a pre-publication copy of his review on potato genetics.

\section{NOTES}

\footnotetext{
${ }^{1}$ URL (accessed 2 October 2007): www.darwinproject.ac.uk (Darwin Correspondence Project. Cambridge University Library).

2 Notes 2 to 6 identify the 141 letters regarding Torbitt's potato project, here referred to as calendar numbers in Burkhardt and Smith (1994). The year (1876-1882) is indicated in bold.
} 
James Torbitt (hereafter JT) to Charles Darwin (hereafter CD), 50 letters:

1876: $10365,10437,10441,10443,10448,10456,10458,10466$

1877: 10881

1878: $11373,11382,11403,11424,11426,11430,11440,11441,11462,11568,11689$

1879: 11696, 11721, 11724, 11787, 11814, 12020, 12023, 12233, 12292, 12322, 12332, 12337, 12370

1880: $12381,12472,12507,12516,12517,12534,12557,12605,12622,12635,12728,12905,12915,12934$

1881: $12995,13083,13168$

CD to JT, 43 letters:

1876: $10368,10440,10442,10451,10463$

1877: 11081, 11296, 1878, 11378, 11383, 11387, 11399, 11413, 11434, 11436, 11458, 11468, $11574,11772$.

1879: $12021,12286,12297,12326,12372$.

1880: $12511,12520,12521,12530,12535,12538,12539,12552,12555,12602,12637,12731,12780,12910$

12925, 12938.

1881: $12966,13086,13165$.

1882: 13608

${ }^{3}$ As note 2, five letters between Charles Darwin (CD) and Joseph Hooker (hereafter JDH):

CD to JDH: 1878: 11380, 11386, 11390; JDH to CD: 1878: 11391, 11417.

${ }^{4}$ As note 2, seven letters between Charles Darwin (CD) and James Caird (hereafter JC):

CD to JC: 1880: 12546, 12547, 12548; JC to CD: 1878: 11437; 1880: 12549, 12753; 1881: $12974 f$.

${ }^{5}$ As note 2, 32 letters between Charles Darwin (CD) and T. H. Farrer (hereafter THF):

CD to THF: 1878: $11388,11389,11397,11401,11406,11407,11412,11421,11447,11457$.

1879: $12268,12288,12325,12479,12512,12523,12528$.

1881: $12956,1882,13608$ a.

THF to CD: 1878: 11384, 11409, 11410, 11435, 11454, 11494.

1879: $12279,12395,12522,12526,12527,12533$.

1882: 13617 .

${ }^{6}$ As note 2, four miscellaneous letters mentioning Torbitt's project:

JC to THF: 1878: $11394 f ; 1880: 12525$.

J. W. P. Bloomfield (secretary to Lord Sandon) to John Lubbock: 1880: 12515.

E. J. A. Bristow to Emma Darwin: 1878: 11414 (on Torbitt's local standing).

${ }^{7}$ JT to CD, 24 January 1876: original ms in Cambridge University Library, Darwin Papers (hereafter CUL, DAR) class 178, letter 130: Burkhardt and Smith (1994) 10365.

The enclosure appears to be lost; it is not found in the Darwin Archive in Cambridge University Library. Both Torbitt and Darwin referred in this correspondence to the "Belfast Journal" but no such title can be found in local libraries, nor is it mentioned by Oram (1983).

${ }^{8}$ CD to JT, 26 January 1876: CUL, DAR 148, 91: 10368 (note 7).

${ }^{9}$ JT to CD, 1 April 1876: CUL, DAR 178, 131: 10437 (note 7).

${ }^{10}$ Kolokol is one of the largest bells in the world, now in the Kremlim Museum.

${ }^{11}$ CD to JT, 4 April 1876: CUL, DAR 148, 92: 10440 (note 7).

${ }^{12}$ CD to JT, 21 April 1876: CUL, DAR 148, 94, 202, 88: 10463 (note 7).

${ }^{13}$ JT to CD, 22 April 1876: CUL, DAR 178, 135: 10466 (note 7).

${ }^{14}$ Lord Stanley to JT, 29 December 1877: CUL, DAR 177, 245: 11296 (note 7).

15 JT to CD, 8 October 1878: CUL, DAR 178, 148: 11721 (note 7).

${ }^{16}$ JT to CD, after 18 October 1878: CUL, DAR 178, 149: 11724 (note 7).

17 JT to CD, late November 1879: CUL, DAR 178, 245: 12337 (note 7).

${ }^{18}$ JT to CD, 24 March 1878: CUL, DAR 178, 142: 11440 (note 7).

${ }^{19}$ CD to JT, 26 February 1878: CUL, DAR 148, 96: 11378 (note 7). 
${ }^{20}$ CD to JT, 28 February 1878: CUL, DAR 148, 97: 11383 (note 7).

${ }^{21} \mathrm{CD}$ to JDH, 28 February 1878: CUL, DAR 95, 449: 11380 (note 7).

${ }^{22}$ CD to JT, 1 March 1878: CUL, DAR 148, 98: 11387 (note 7).

${ }^{23}$ CD to JDH, 2 March 1878: CUL, DAR 95, 453- 4: 11390 (note 21).

${ }^{24} \mathrm{CD}$ to JDH, 1 March 1878: CUL, DAR 95, 451- 2: 11386 (note 21).

${ }^{25}$ Letters mentioning that money has been sent to Torbitt (Burkhardt and Smith 1994): 1880: 11458 (CD sends $£ 100$ ), 12520 (CD sends £50), 12530 (CD sends £170); 1881: 13165 (CD sends £90).

26 JC to THF, 2 March 1878: CUL. DAR 144, 2: 11394f (see note 7).

${ }^{27}$ CD to THF, 4 March 1878: CUL, DAR 148, 99: 11397 (see note 7).

${ }^{28}$ CD to THF, 23 October 1879: CUL, DAR 144, 97: 12268 (note 7).

${ }^{29}$ CD to JT, 1 November 1879: CUL, DAR 148: 107: 12286 (note 7).

${ }^{30}$ JT to CD, 12 February 1880 CUL, DAR 144, 486: 12472 (note 7).

${ }^{31} \mathrm{JC}$ to CD, 25 Mach 1880: CUL, DAR 52, E7b: 12549 (note 7).

32 CUL, DAR 52 E2 (note 7). Notes 32 to 36 refer to printed items. However, these items are printed on one side only and the Darwin Archive at CUL indicates either "Source unknown" (items E2 and E4), or "private" (items E5 and E6). As is clear from some of the letters quoted here, Torbitt sometimes printed letters for private distribution (see, for example, CD to JDH, 28 February 1878: CUL, DAR 95, 449: 11380).

${ }^{33}$ CUL, DAR 52 E3 (notes 7 and 32).

${ }^{34}$ CUL, DAR 52 E4 (notes 7 and 32).

${ }^{35}$ CUL, DAR 52 E5 (notes 7 and 32).

${ }^{36}$ CUL, DAR 52 E6 (notes 7 and 32).

${ }^{37}$ CUL, DAR 178 (note 7).

${ }^{38}$ CD to JT, 18 May 1881: CUL, DAR 148, 129: 13165 (note 7).

\section{REFERENCES}

ANONYMOUS, 1874 British Association for the Advancement of Science, Belfast meeting. The Times 21 August: 6.

ANONYMOUS, 1879 The potato show. The Times 18 September: 10.

ANONYMOUS, 1880 Select parliamentary committee report on the failure of the potato crop. 1880 12: 309.

BOURKE, A., 1962 The scientific investigation of the potato blight 1845-6. Irish historical studies 13: 26-32.

BOURKE, A., 1964 Emergence of the potato blight 1843-6. Nature 203: 805-808.

BOURKE, A., 1993 The visitation of God? The potato and the great Irish famine. Dublin: Lilliput Press.

BURKHARDT, F. and SMITH, S. (editors), 1994 A calendar of the correspondence of Charles Darwin 1821-1882. Cambridge: Cambridge University Press.

CHAMBERLAIN, M. E., 2004 Stanley, Henry Edward John, third Baron Stanley of Alderley and second Baron Eddisbury (1827-1903). Oxford dictionary of national biography. Oxford: Oxford University Press.

CLARK, J. J., 1880 The Irish potato crop. The Times 17 February: 8.

CLARKE, R. S. J. (editor), 1986 Gravestone inscriptions. Volume 1. Shankhill graveyard and tablets in Christ Church and St George's Church. Belfast: Ulster Historical Foundation.

COllins, A., Milbourne, D., RAMSAY, L., MEYER, R., CHATOT-BAlANDRAS, C., OBERHAGEMANN, P., DE JONG, W., GEBHARDT, C., BONNEL, E. and WAUGH, R., 1999 QTL for field resistance to late blight in potato are strongly correlated with maturity and vigour. Molecular breeding 5: 387-398.

DALY, M. E., 1995 The operation of famine relief, 1845-57, pp 123-135 in POIRTER, C. (editor), The great Irish famine. Dublin: RTE/Mercier Press.

DARWIN, C. R., 1859 On the origin of species by means of natural selection. London: John Murray.

DARWIN, C. R., 1880 Sir Wyville Thompson and natural selection. Nature 23: 32. 
DARWIN, F., 1887 The life and letters of Charles Darwin. London: John Murray.

DAVIDSON, W. D., 1928a A review of the literature dealing with the degeneration of varieties of the potato. Economic proceedings of the Royal Dublin Society 20: 331-387.

DAVIDSON, W. D., 1928b The rejuvenation of the Champion potato. Economic proceedings of the Royal Dublin Society 20: 319-330.

DAVIDSON, W. D., 1939 Famous potato raisers. Journal of the Royal Agricultural Society of England, 100: 1-22.

EVANS, A., COOKE, L. and CLINT, J., 1996 'Too serious for joking': James Torbitt, the Belfast potato breeder. Ulster folklife 42: 1-11.

FUGLIE, K. O., DO THI B, N., HUY CHIEN, D. and THI HOA, N., 2001 The economic impact of true potato seed in Vietnam. Mexico: International Potato Centre.

GÓMEZ-ALPIZAR, L., CARBONE, I. and RISTAINO, J. B., 2007 An Andean origin of Phytophthora infestans inferred from mitochondrial and nuclear gene genealogies. Proceedings of the National Academy of Science 104: 3306-3311.

KINEALY, C., 1994 The great calamity. Dublin: Gill \& Macmillan.

MILBOURNE, D., PANDE, B. and BRYAN, G., 2007 Potato, in volume 3, pp 205-236, KOLE, C. (editor), Genome mapping and molecular breeding in plants. Pulses, sugar and tuber crops. Berlin \& Heidelberg: Springer Verlag.

NELSON, E. C., 1983 David Moore, Miles J. Berkeley and scientific studies of potato blight in Ireland, $1845-1847$. Archives of natural history 11: 249-261.

NELSON, E. C., 1995 The cause of the calamity: potato blight in Ireland, 1845-1847, and the role of the National Botanic Gardens, Glasnevin. Dublin: Stationery Office.

NELSON, E. C. and SEAWARD, M. R. D., 1981 Charles Darwin's correspondence with David Moore of Glasnevin on insectivorous plants and potatoes. Biological journal of the Linnean Society 15: 157-164.

O'BRIEN, W. P., 1896 The great famine in Ireland. A retrospective of 50 years. London: Downey \& Co.

O'NEILL, T. P., 1946 The scientific investigation of the failure of the potato crop in Ireland, 1845-6. Irish historical studies 5: 123-138.

O’NEILL, T. P., 1995 The persistence of famine in Ireland, pp 204-219 in POIRTER, C. (editor), The great Irish famine. Dublin: RTE/Mercier Press.

ORAM, H., 1983 The newspaper book: a history of newspapers in Ireland, 1649-1983. Dublin: MO Books.

SALAMAN, R. N., 1910 The inheritance of colour and other characters in the potato. Journal of genetics 1: 7-46.

SALAMAN, R. N., 1949 The history and social importance of the potato. Cambridge: Cambridge University Press.

TORBITT, J., 1875 Potato cultivation. Proceedings of Belfast Natural Historical and Philosophical Society: $112-125$.

TORBITT, J., 1876 A treatise on the cultivation of the potato from the seed, having for proposed results the extinction of the disease, and a yield of thirty, forty or more tons of tubers per statute acre. Belfast: [the author].

VEAK, T., 2003 Exploring Darwin's correspondence: some important but lesser known correspondents and projects. Archives of natural history 30: 118-138. 